\title{
Viral and bacterial serology of six free-ranging bearded seals Erignathus barbatus
}

\author{
Paul P. Calle ${ }^{1, *}$, Dana J. Seagars ${ }^{2,6}$, Catherine McClave ${ }^{3}$, Dennis Senne ${ }^{4}$, \\ Carol House ${ }^{5}$, James A. House ${ }^{5}$
}

\begin{abstract}
${ }^{1}$ Global Health Programs, Wildlife Conservation Society, 2300 Southern Blvd., Bronx, New York 10460-1099, USA ${ }^{2}$ US Fish and Wildlife Service, Marine Mammals Management, 1011 E. Tudor Road, Anchorage, Alaska 99503, USA ${ }^{3}$ New York Aquarium, Wildlife Conservation Society, Surf Avenue \& West 8th Street, Brooklyn, New York 11224, USA ${ }^{4}$ National Veterinary Services Laboratories, Ames, Iowa 50010, USA

${ }^{5}$ Foreign Animal Disease Diagnostic Laboratory, USDA, APHIS-VS-NVSL, Plum Island, New York 11944, USA
\end{abstract}

${ }^{6}$ Present address: US Fish and Wildlife Service, Ecological Services, 605 W. Fourth Avenue, Anchorage, Alaska 99501, USA

\begin{abstract}
Serum or heparinized plasma samples were obtained from 3 male (2 adult and 1 weaned calf) and 3 adult female free-ranging bearded seals Erignathus barbatus in May of 1994, 1995, or 1996. Blood samples were obtained from animals taken in subsistence hunts near St. Lawrence Island, Alaska and screened for antibodies to a suite of bacteria and viruses potentially pathogenic for pinnipeds and/or humans. No samples had detectable antibodies to Brucella spp., Phocine distemper virus, influenza A virus or caliciviruses (San Miguel sea lion virus strains 1, 2, and 4 to 13, vesicular exanthema of swine serotypes A48, B51, C52, D53, E54, F55, G55, H54, I55, J56, K54, 1934B, and Tillamook and Walrus calicivirus). One seal had a low titer of 100 to Leptospira interrogans serovar grippotyphosa.
\end{abstract}

KEY WORDS: Leptospira interrogans $\cdot$ Brucella $\cdot$ Phocine distemper virus · Influenza A virus Calicivirus · Bearded seal · Erignathus barbatus $\cdot$ Northern Bering Sea

\section{INTRODUCTION}

Bearded seals Erignathus barbatus are an important subsistence resource for native Alaskans living along the Bering and Chukchi Sea coasts, with an estimated annual harvest of 6788 animals (Angliss \& Lodge 2002). There have been no comprehensive health surveys of this species. However, various bacteria and viruses have caused either localized or widespread morbidity or mortality in other free-ranging pinniped populations. Infections reported include Leptospira spp. (Gulland 1999), Brucella spp. (Nielson et al. 1996, 2001, Tryland et al. 1999), phocine distemper virus (PDV) (Duignan 1999), caliciviruses (Barlough et al. 1986), influenza A virus (Geraci et al. 1982, Danner et al. 1998), and phocid herpesvirus (Zarnke et al. 1997). Although bearded seals have been included in some pinniped infectious disease exposure surveys (Barlough et al. 1987, 1988, Osterhaus et al. 1988, Zarnke et al. 1997, Danner et al. 1998, Tryland et al. 1999), there have been no studies specifically examining exposure of bearded seals to multiple infectious organisms. Our objectives were to determine antibody levels to potential pinniped pathogens or zoonotic organisms in free ranging bearded seals collected opportunistically in the process of monitoring the Pacific walrus Odobenus rosmarus divergens harvest from 1994 to 1996. Testing was conducted for 5 Leptospira interrogans serovars, Brucella spp., PDV, 26 calicivirus strains, and influenza A virus as previously described for Pacific walrus (Calle et al. 2002).

\section{MATERIALS AND METHODS}

Blood samples were collected from 3 male (2 adult and 1 weaned calf) and 3 adult female bearded seals harvested by native Alaskans during May 1994, 1995 
or 1996 in the Bering Sea west and southwest of Gambell $\left(63.781^{\circ} \mathrm{N}, 171.736^{\circ} \mathrm{W}\right)$, St. Lawrence Island, Alaska (Table 1, Fig. 1). Collection of sample material (blood for infectious disease serology testing and organs for contaminant level determination) was authorized by US National Marine Fisheries Service permits 797 and 839. Blood samples were collected into plain or sodium heparin tubes from either freely flowing wounds or from the heart within $5 \mathrm{~min}$ post mortem and held at ambient temperature $\left(-5\right.$ to $\left.+5^{\circ} \mathrm{C}\right)$ until processed. Samples were centrifuged for $15 \mathrm{~min}$ at $1500 \times g$ with a portable centrifuge within $7 \mathrm{~h}$ of collection. Time from centrifugation to freezing of serum or plasma varied from 0.1 to $7.9 \mathrm{~h}$ (mean: $1.5 \mathrm{~h}$ ). In the field, plasma and serum were stored in chest freezers or portable liquid nitrogen tanks for 2 to $3 \mathrm{wk}$ until transferred to a freezer $\left(-20\right.$ or $\left.-70^{\circ} \mathrm{C}\right)$ for intermediate storage prior to shipment by overnight delivery to analysis laboratories, as previously described (Calle et al. 2002).

Serology for 5 Leptospira interrogans serovars (canicola, hardjo, grippotyphosa, icterohaemorrhagiae/copenhageni, pomona) was performed at a veterinary diagnostic laboratory (New York State Diagnostic Laboratory, College of Veterinary Medicine, Ithaca, New York, USA) by the microscopic agglutination test (MAT) (Cole et al. 1979, Rubin et al. 1981, Ellinghausen et al. 1984). A positive test was defined as $50 \%$ or more of the live Leptospira antigen/cells agglutinating at a screening dilution of 1:100, with titers of samples reacting at this dilution determined by assay of serial dilutions of samples. Brucella spp., PDV, and calicivirus serologies were performed at the Foreign Animal Disease Diagnostic Laboratory, USDA, APHISVS-NVSL, Plum Island, New York, USA (FADDL). Undiluted samples were tested by the card test (Miller et al. 1999) for antibodies to B. abortus. If any granularity was observed, the sample was tested for antibodies to $B$. abortus by the tube agglutination test (Miller et al. 1999) using dilutions of 1:25, 1:50, 1:100 and 1:200. Samples agglutinating the slurry completely at 1:25 and incompletely at 1:50 were considered positive for

Table 1. Erignathus barbatus. Identification, collection location, sex, and age class of bearded seals sampled for bacterial and viral serologic testing

\begin{tabular}{|c|c|c|c|}
\hline Identification & Location & Sex & Age class \\
\hline G94-9001 & $63.667^{\circ} \mathrm{N}, 172.003^{\circ} \mathrm{W}$ & Female & Adult \\
\hline G94-9002 & $63.667^{\circ} \mathrm{N}, 172.003^{\circ} \mathrm{W}$ & Female & Adult \\
\hline G95-0746 & $63.535^{\circ} \mathrm{N}, 172.736^{\circ} \mathrm{W}$ & Male & Adult \\
\hline G96-9001 & $63.461^{\circ} \mathrm{N}, 172.681^{\circ} \mathrm{W}$ & Male & Adult \\
\hline G96-9002 & $63.816^{\circ} \mathrm{N}, 172.243^{\circ} \mathrm{W}$ & Female & Adult \\
\hline G96-9003 & $63.819^{\circ} \mathrm{N}, 171.940^{\circ} \mathrm{W}$ & Male & Calf \\
\hline
\end{tabular}

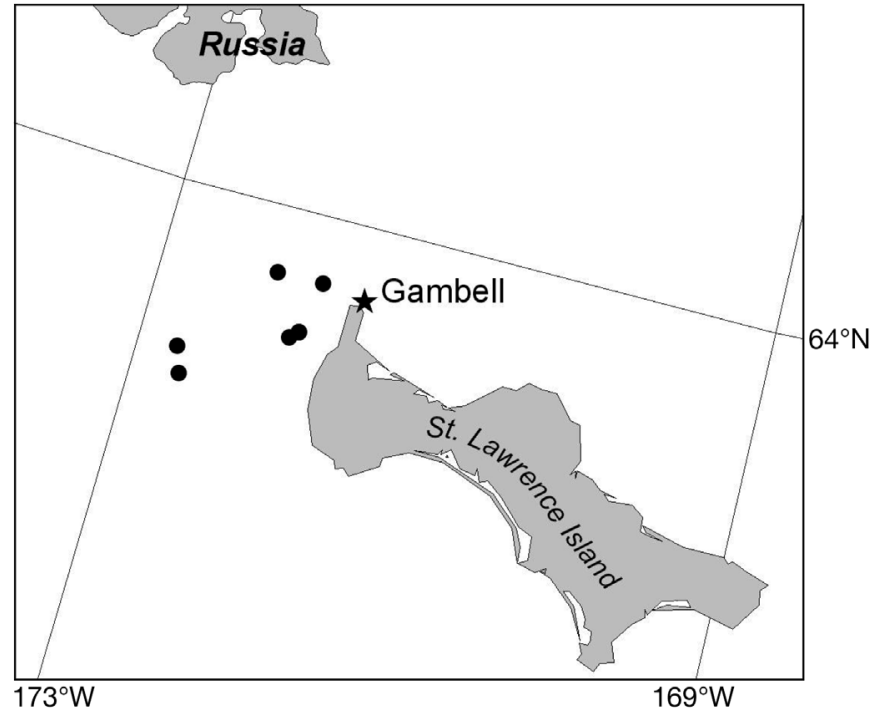

Fig. 1. Erignathus barbatus. Collection locations (๑) of bearded seals sampled for bacterial and viral serologic testing. See Table 1 for geographic coordinates of locations

antibodies to Brucella. Samples were serially diluted from 1:20 to $1: 160$ and tested by virus neutralization for antibodies to PDV (Duignan et al. 1994). Control wells observed to be contaminated by bacteria or to be nonspecifically toxic to Vero cells were recorded as toxic and the sample was regarded as negative at the dilution tested. Test wells exhibiting cytopathic effects typical of the virus were recorded as positive. Samples were serially diluted from 1:20 to 1:180 and tested by virus neutralization tests for antibodies to a panel of caliciviruses. Samples from all 6 animals were tested for San Miguel sea lion virus strains 1, 2, 4 to 13 and vesicular exanthema of swine strains A48, B51, C52, D53, E54, F55, G55, H54, I55, J56, K54, 1934B, and from 5 animals for Tillamook and Walrus calicivirus (O'Hara et al. 1998). Determinations of the toxicities and endpoint titers of the sample were as described for PDV serological testing. Samples were considered positive for antibodies to a serotype of calicivirus if the endpoint titer was $\geq 32$. Samples from 3 animals were tested at the National Veterinary Services Laboratories, Ames, Iowa, USA (NVSL) for antibodies to influenza A virus by the agar gel immunodiffusion (AGID) test. Samples precipitating the test antigen and forming a line of identity with the reference reagent serum were considered positive.

\section{RESULTS}

No seals had antibody titers to Brucella spp., PDV, influenza A or any calicivirus strain. One adult male 
seal (G969001) had a low titer of 100 to Leptospira interrogans serovar grippotyphosa and all were negative for antibodies to the other $L$. interrogans serovars.

\section{DISCUSSION}

The low Leptospira titer observed might represent exposure to Leptospira interrogans serovar grippotyphosa, cross-reaction between serovars of Leptospira that were not assayed for in this study, or nonspecific responses (Calle et al. 2002). California sea lions Zalophus californianus with titers to L. interrogans serovar grippotyphosa have been observed (Gulland et al. 1996, Godinez et al. 1999). Renal disease in Pacific harbor seals Phoca vitulina richardsi and asymptomatic infection in elephant seals Mirounga angustirostris with this serovar have been documented (Stamper et al. 1998). Sympatric Pacific walrus have also demonstrated titers to L. interrogans serovar grippotyphosa (Calle et al. 2002). Bearded seals have not previously been determined serologically positive for $L$. interrogans serovars. L. interrogans serovar pomona infection is common in northern fur seals Callorhinus ursinus (Smith et al. 1977) and California sea lions (Gulland 1999), but no serological evidence of infection with this serovar was observed in these bearded seals.

Both Atlantic and Pacific pinnipeds with serological evidence of Brucella spp. infection have been reported (Nielson et al. 1996, 2001, Tryland et al. 1999), although bearded seals were not positive (Tryland et al. 1999). In a previous survey, no Pacific walrus sympatric with these bearded seals had Brucella spp. antibodies (Calle et al. 2002).

Harbor seal Phoca vitulina and grey seal Halichoerus grypus PDV epizootics have been recorded (Osterhaus et al. 1988, Duignan 1999). Antibodies to PDV have been reported in Atlantic walrus Odobenus rosmarus rosmarus (Duignan et al. 1994), but not in Pacific walrus (Osterhaus et al. 1988, Calle et al. 2002) nor in a number of other Arctic pinniped species tested, including the bearded seal (Osterhaus et al. 1988). Eastern Arctic species, however, have antibodies to PDV (Duignan et al. 1997). At this time there is no evidence that PDV has been introduced to North American Pacific coast pinniped populations (Duignan et al. 1995, Kennedy 1998, Ham-Lamme et al. 1999).

Based upon virus isolation or serological surveys, multiple serotypes of influenza A virus have been documented in Atlantic harbor and gray seals (Webster et al. 1981, Geraci et al. 1982), but there is no serological evidence of influenza in northern fur seals sampled from the Bering Sea, Pacific Ocean, and Sea of Okhotsk (Webster et al. 1981). In a survey of Alaskan pinniped species (including Pacific walrus and bearded seal) (Danner et al. 1998), only 1 ringed seal Phoca hispida had antibody to influenza A. In contrast, a serological survey of Pacific walrus (Calle et al. 2002) provided evidence of exposure to a range of influenza A strains.

There are multiple reports documenting calicivirus exposure in a range of eastern Pacific, Arctic or Bering Sea marine mammals (Barlough et al. 1986, 1987, 1988, O'Hara et al. 1998, Calle et al. 2002). Although it appears that some of these calicivirus strains may be enzootic in several marine mammal species in the Arctic ecosystem, none of the bearded seals sampled displayed serological evidence of calicivirus infection, nor did bearded seals in other studies (Barlough et al. 1987, 1988).

Leptospira, Brucella, caliciviruses and influenza A virus are potential zoonotic diseases. Influenza A conjunctivitis has occurred in biologists and veterinarians working with infected pinnipeds (Webster et al. 1981). Humans have also been reported to develop either clinical leptospirosis or Leptospira antibody titers after exposure to Leptospira-infected pinnipeds (Gulland 1999). Investigators have developed calicivirus antibodies after working with infected pinnipeds (Barlough et al. 1986). Infected pinnipeds also pose a potential health risk to the Inupiat and Yupik hunters who utilize them as food sources (Calle et al. 2002).

Our study is the first to examine exposure of bearded seals to a range of infectious agents, contributes to knowledge of the population's exposure to potentially pathogenic bacteria and viruses, and establishes baseline exposure status. There were too few animals tested to adequately assess potential differences in exposure based on age, sex, or collection location. The results suggest that the population may not have been exposed to influenza A viruses, caliciviruses, PDV, Brucella spp., and has had only limited, if any, exposure to Leptospira spp. As has been postulated for other immunologically naive pinniped populations, the bearded seal population could be adversely affected were novel pathogens introduced (Duignan et al. 1994, 1995, Danner et al. 1998, Kennedy 1998, Ham-Lamme et al. 1999, Calle et al. 2002); this could have adverse consequences for both bearded seal populations and native Alaskan subsistence.

Acknowledgements. The authors acknowledge T. Fischbach and S. Rice, US Fish and Wildlife Service; and N. Tileston and S. Prien, the Alaska Resources Library, Anchorage. Drs. D. DeMaster and P. Becker, National Marine Fisheries Service arranged for collection activities to be included within appropriate research permits. Most importantly, we acknowledge and thank native Alaskans without whose assistance this project would not have been possible: Gambell walrus hunters W. Ohktokiyuk, D. James Jr. \& Sr., W. James, J. \& R. Nowpakahok, D. Angie, L. Apangalook Sr., V. Slowko Jr. and D. Ungott; and walrus monitors M. Ungott and S. Nowpakahok. 


\section{LITERATURE CITED}

Angliss RP, Lodge KL (2002) Alaska marine mammal stock assessments, 2002. US Department of Commerce, NOAA Technical Memo NMFS-AFSC 133:51-54

Barlough JE, Berry ES, Skilling DE, Smith AW (1986) The marine calicivirus story - Part II. Compend Contin Educ Pract Vet 8:F75-F82

Barlough JE, Berry ES, Smith AW, Skilling DE (1987) Prevalence and distribution of serum neutralizing antibodies to Tillamook (Bovine) calicivirus in selected populations of marine mammals. J Wildl Dis 23:45-51

Barlough JE, Berry ES, Skilling DE, Smith AW (1988) Prevalence and distribution of serum neutralizing antibodies to San Miguel sea lion virus types 6 and 7 in selected populations of marine mammals. Dis Aquat Org 5:75-80

Calle PP, Seagars DJ, McClave C, Senne D, House C, House JA (2002) Viral and bacterial serology of free-ranging Pacific walrus. J Wildl Dis 38:93-100

Cole JR, Ellinghausen HC, Rubin HL (1979) Laboratory diagnosis of leptospirosis of domestic animals. Proc Annu Meet US Anim Health Assoc 83:189-195

> Danner GR, Mcgregor MW, Zarnke RL, Olsen CW (1998) Serologic evidence of influenza virus infection in a ringed seal (Phoca hispida) from Alaska. Mar Mamm Sci 14: 380-384

Duignan PJ (1999) Morbillivirus infections of marine mammals. In: Fowler ME, Miller RE (eds) Zoo and wild animal medicine, current therapy 4. WB Saunders Company, Philadelphia, PA, p 497-501

Duignan PJ, Saliki JT, St. Aubin DJ, House JA, Geraci JR (1994) Neutralizing antibodies to phocine distemper virus in Atlantic walrus (Odobenus rosmarus rosmarus) from Arctic Canada. J Wildl Dis 30:90-94

Duignan PJ, Saliki JT, St. Aubin DJ, Early G and others (1995) Epizootiology of morbillivirus infection in North American harbor seals (Phoca vitulina) and gray seals (Halichoerus grypus). J Wildl Dis 31:491-501

Duignan PJ, Nielsen O, House C, Kovacs KM and others (1997) Epizootiology of morbillivirus infection in harp, hooded, and ringed seals from the Canadian Arctic and western Atlantic. J Wildl Dis 33:7-19

Ellinghausen HC, Rubin HL, Cole JR (1984) Laboratory diagnosis of leptospirosis of domestic animals. III. Serological characterization. Proc Annu Meet US Anim Health Assoc 88:214-224

Geraci JR, St. Aubin DJ, Barker IK, Webster RG and others (1982) Mass mortality of harbor seals: pneumonia associated with influenza A virus. Science 215:1129-1131

Godinez CR, De Romillo BZ, Aurioles-Gamboa D, VerdugoRodriguez A, Rodriguez-Reyes EA, De La PenaMoctezuma A (1999) Antibodies against Leptospira interrogans in California sea lion pups from Gulf of California. J Wildl Dis 31:108-111

Editorial responsibility: Michael Moore, Woods Hole, Massachusetts, USA
Gulland FMD (1999) Leptospirosis in marine mammals. In: Fowler ME, Miller RE (eds) Zoo and wild animal medicine, current therapy 4. WB Saunders Company, Philadelphia, PA, p 469-471

Gulland FM, Koski M, Lowenstine LJ, Colagross A, Morgan L, Spraker T (1996) Leptospirosis in California sea lions (Zalophus californianus) stranded along the Central California coast, 1981-1994. J Wildl Dis 32:572-580

> Ham-Lamme KD, King DP, Taylor BC, House C and others (1999) The application of immuno-assays for serological detection of morbillivirus exposure in free ranging harbor seals (Phoca vitulina) and sea otters (Enhydra lutris) from the western coast of the United States. Mar Mamm Sci 15:601-608

Kennedy S (1998) Morbillivirus infections in aquatic mammals. J Comp Pathol 119:201-225

Miller WG, Adams LG, Ficht TA, Cheville NF and others (1999) Brucella-induced abortions and infection in bottlenose dolphins (Tursiops truncatus). J Zoo Wildl Med 30: $100-110$

Nielsen O, Nielsen K, Stewart REA (1996) Serologic evidence of Brucella spp. exposure in Atlantic walrus (Odobenus rosmarus rosmarus) and ringed seals (Phoca hispida) of Arctic Canada. Arctic 49:383-386

Nielsen O, Stewart REA, Neilsen K, Measures L, Duignan P (2001) Serologic survey of Brucella spp. antibodies in some marine mammals of North America. J Wildl Dis 37:89-101

O'Hara TM, House C, House JA, Suydam RS, George JC (1998) Viral serologic survey of bowhead whales in Alaska. J Wildl Dis 34:39-46

Osterhaus ADME, Groen J, DeVries P, Uytdehaag FGCM, Klingeborn B, Zarnke R (1988) Canine distemper virus in seals. Nature 335:403-404

Rubin HL, Cole JR, Ellinghausen HC (1981) Laboratory diagnosis of leptospirosis of domestic animals. II. Isolation procedures. Proc Annu Meet US Anim Health Assoc 85:203-211

> Smith AW, Brown RJ, Skilling DE, Bray HL, Keyes MC (1977) Naturally occurring leptospirosis in Northern fur seals (Callorhinus ursinus). J Wildl Dis 13:144-148

Stamper MA, Gulland FMD, Spraker T (1998) Leptospirosis in rehabilitated Pacific harbor seals from California. J Wildl Dis 34:407-410

Tryland M, Kleivane L, Alfredsson A, Kjeld M, Arnason A, Stuen S, Godfroid J (1999) Evidence of Brucella infection in marine mammals in the North Atlantic Ocean. Vet Rec 144:588-592

> Webster RG, Hinshaw VS, Bean WJ, Van Wyke KL, Geraci JR, St. Aubin DJ, Petursson G (1981) Characterization of an influenza A virus from seals. Virology 113:712-724

Zarnke RL, Harder TC, Vos HW, Ver Hoef JM, Osterhaus ADME (1997) Serologic survey for phocid herpesvirus-1 and -2 in marine mammals from Alaska and Russia. J Wildl Dis 33:459-465

Submitted: October 19, 2006; Accepted: November 28, 2006 Proofs received from author(s): July 28, 2008 